\title{
O SOCIALISMO REAL: UM BALANÇO
}

\author{
Aldo Agosti \\ Professor de História Contemporânea da Universidade de Turim - Itália
}

\begin{abstract}
"Socialismo real", "socialismo realmente existente", "socialismo realizado": todas essas definições, cunhadas pelos grupos dirigentes dos partidos comunistas no poder, durante o período brezneviano, passaram a fazer parte da linguagem política corrente em meados dos anos '70 para designar, de fato, em polêmica com o euro-comunismo que teorizava uma "terceira via" entre modelo soviético e socialdemocracia, a realidade política e social dos países pertencentes ao bloco socialista, e foram consideradas, desde então, substancialmente como sinônimos. Na realidade, seria interessante reconstruir a história de cada uma dessas definições, porque cada uma delas oculta, mesmo que inconscientemente, algumas nuanças. "Socialismo real", por si mesmo, é uma expressão ambígua: quando foi cunhada ela podia significar o socialismo que existia de fato e, consequientemente, relegar o restante (isto é, as diversas formas possíveis de socialismo em relação àquele, de fato, "real") no campo das discussões acadêmicas ou, mais duramente, das aspirações veleitárias; mas podia deixar entender, também, que existisse, ainda, um hiato a ser preenchido entre a realidade e o ideal. Ao contrário, a segunda das definições - "socialismo realmente existente" - era mais programática mas, ao mesmo tempo, mais unívoca,
\end{abstract}

\footnotetext{
* Conferência proferida em 24 de abril de 2002 no Depto. de História-FFLCH/USP. Tradução do
} Prof. Dr. Adone Agnolin - Depto. de História-FFLCH/USP. 
e parecia resolver qualquer possível ambivalência no sentido do primeiro ponto do dilema, concentrando a atenção sobre o socialismo que "existia" historicamente. A terceira expressão, "socialismo realizado", evocava, por sua vez, duas possíveis chaves de leitura: um processo em andamento, susceptível, portanto, de acabamentos e melhorias (o socialismo "até agora" realizado), ou uma construção completada, um caminho que chegou à sua etapa final.

Querendo propor um balanço das experiências dos sistemas políticos e econômicos que se chamaram socialistas, dez anos e mais após sua definitiva conclusão, pelo menos na Europa, das três definições acima apontadas, aquela que parece mais útil é a terceira: pelo menos levando em consideração o fato de que abre o caminho à possibilidade de cindir a expressão em seus dois termos, o substantivo e o particípio passado. Um balanço, de fato, teria que levar em consideração, por um lado, aquilo que as experiências em questão significaram para o socialismo, entendido como ideal de resgate, de emancipação dos oprimidos e de fraternidade universal, e, por outro lado, as concretas realizações que elas deixaram de si.

A partir do primeiro ponto de vista, o balanço não pode ser, senão, ao final, pesadamente negativo. O socialismo, sobretudo o socialismo que foi prometido às populações de uma parte do continente devastada pela guerra e passara antes, com poucas excessões, por um período de opressão social e de aguda crise econômica, foi uma ideologia que prometia igualdade e prosperidade: da primeira restavam, no fim dos anos '70, poucas marcas, da segunda não havia nem mesmo uma sombra. A promessa de elevação dos padrões de vida da população não foi sempre só propaganda vazia; mas justamente por causa disso, agora que estes padrões (de vida) precipitavam para baixo (e o quanto para baixo era possível aos interessados constatá-lo graças à maior liberdade de circulação das pessoas, ou pelo menos à difusão do rádio e das televisões do Ocidente), a exigência insatisfeita daquela promessa, aliás, seu reviramento numa tétrica condição de penúria, representava um golpe gravíssimo, infligido à pretensão de legitimidade dos sistemas que se reivindicavam socialistas, ou melhor, que haviam cultivado a pretensão de incarnar o socialismo realmente existente. Portanto, os dirigentes comunistas do Leste-incluindo aqueles, e não eram muitos, que não haviam deixado, havia bastante tempo, de acredi- 
tar em sua própria propaganda -, quando, quase sem exceção, deixaram pacificamente o poder em 1989, tomaram consciência de uma falência para a qual não parecia mais possível encontrar um remédio no interior do sistema.

Com certeza, como observava em um de seus últimos livros Giuseppe Boffa entre os mais lúcidos historiadores dos países do "socialismo real”, hoje injustamente quase esquecido -, seria errado "reduzir a experiência dos governos comunistas da Europa centro-oriental a uma simples violência exercida sobre populações recalcitrantes, ou a uma arbitrária imposição de uma ideologia preconcebida, além do mais vinda do exterior". Houve isso também, mas não somente isso. Não poucos partidos comunistas conseguiram tecer ligações profundas e resistentes com diversas camadas da população, por meio de uma difusão capilar de sua influência, forjando uma determinada consciência social, um determinado tipo de opinião pública, um tipo e estrutura particular de reivindicações materiais, de expectativas e de necessidades. Mas aquelas ligações foram se desgastando cada vez mais. Os regimes comunistas do Leste europeu, e mais ainda seu modelo original, a URSS, tornaram-se cada vez mais, por muitos aspectos e de forma totalmente evidente no decorrer dos anos ' 80 , estruturas externas quase completamente esvaziadas de seu conteúdo originário, eficazes quase somente seja como aparato repressivo, seja como pára-vento ideológico para paralisar a maturação de uma alternativa.

O panorama deixado atrás de si pelo socialismo realizado é, portanto, por muitos aspectos, um panorama de desolação social, de corrupção política e moral, de apatia, de desânimo. Com certeza não é fácil medir quanto deste panorama pertence à herança negativa deixada por aqueles sistemas, e quanto, ao contrário, também é imputável à adoção enlouquecida de um modelo de privatização selvagem da economia, que produziu o enriquecimento de poucos e o empobrecimento de uma grande maioria da população. As situações são muito diferentes, dependendo também dos espaços que foram deixados antes de 1989 à auto-organização espontânea da sociedade civil e, portanto, à criação pelo menos embrionária, de uma nova classe dirigente.

Por outro lado, se deslocarmos a atenção para o segundo termo do binômio e olharmos para as "realizações" dos sistemas socialistas, prescindindo de sua corres- 
pondência aos ideais do socialismo, não poderemos deixar de reconhecer, acredito, que elas mudaram a face das realidades dentro das quais tomaram forma, e não somente para pior.

No que diz respeito à Rússia, não há dúvida que a revolução de outubro foi um potente fator de modernização do país: em quarenta anos, a Urss se transformou, de um país atrasado e essencialemente camponês, numa grande potência industrial. De fato, na segunda metade do século XX, o modelo de comunismo soviético tornouse, antes de mais nada, um programa para transformar os países atrasados em países avançados, uma espécie de atalho para a modernização. Entre as duas guerras, especialmente nos anos '30, a taxa de crescimento da economia soviética superou a maior parte dos países europeus e durante os primeiros quinze anos depois da Segunda Guerra mundial as economias do "campo" socialista cresceram de forma consideravelmente mais rápida que as do Ocidente. Na medida em que a modernização pode ser identificada com o progresso, é difícil negar que a Revolução Russa tenha sido, e não somente em termos econômicos, um fato progressivo. A transformação de um país predominantemente analfabeto num Estado moderno, com altos níveis de escolarização e pontas de excelência na pesquisa científica, não é um detalhe secundário. Para milhões de pessoas significou uma via de saída do obscurantismo e da ignorância, perspectivas de avanço social e abertura de novos horizontes culturais. E, em escala mais reduzida, o fenômeno se reproduziu naquelas "democracias populares" que descontavam um passado de atraso (isto é, todas menos a Checoslováquia e a República Democrática Alemã). Naturalmente, os preços dessa modernização foram extremamente pesados em termos sociais e humanos, e os sucessos alcançados pela industrialização nunca foram igualados pela agricultura e pela distribuição; permanece em aberto, além do mais, o problema de se pudessem ser percorridas alternativas menos carregadas de "lágrimas e sangue". A maior parte dos países que experimentaram o "socialismo real”, não é inútil lembrá-lo, havia conhecido, sobretudo, regimes autoritários ou formas de democracia no mínimo mutiladas: as eleições que se realizavam antes da Segunda Guerra mundial não eram muito mais livres daquelas que tiveram lugar depois de 1947. Representar sua 
"sovietização" como uma caída do reino da liberdade para aquele da ditadura constitui, pois, uma maneira de forçar as coisas. Em contrapartida, resulta inegável que foi quebrado, uma vez por todas, o poder de classes dirigentes ávidas e corruptas (especialmente os grandes proprietários de terras) e que um modesto teor de vida foi garantido a todos, com um alargamento dos direitos de cidadania social. Isto não significa, necessariamente, que essas realizações não teriam tido a possibilidade de se realizar, também, com um modelo diferente daquele socialista, nem que não poderiam ter sido conseguidas com menores custos sociais e humanos, com um mais alto grau de participação popular e com uma maior (garantia) das liberdades fundamentais: mas aqui aventura-se no terreno sempre inacessível da história contra-factual. Aquilo que é impossível ignorar é que, de qualquer forma, à herança do "socialismo real" pertencem, também, essas profundas transformações econômicas, sociais e civis.

O problema é que, a partir de um certo momento, essas transformações deixaram de ser o motor de um progresso geral das sociedades das quais haviam transformado a face. E aquelas sociedades se emaranharam nas contradições de um crescimento sem desenvolvimento, na impossibilidade de uma auto-reforma (como emergiu dramaticamente em 1968 na Checoslováquia); no fim perderam o desafio com o capitalismo também no plano econômico. No plano político o desafio já fora perdido desde o começo dos anos Cinqüenta, quando a repressão, o controle completo da polícia secreta, o sufocamento da liberdade intelectual e das formas de auto-organização da classe operária, a esclerotização de uma burocracia cada vez mais distante dos cidadãos, tornaram-se seu traço dominante e inverteram as promessas do futuro socialista em sua negação. 